\title{
Removal of hexavalent chromium from graphene oxide supported on a cellulose acetate and polyacrylic acid membrane
}

\section{Remoción de cromo hexavalente a partir óxido de grafeno soportado en una membrana de acetato de celulosa y ácido poliacrílico}

\author{
SÁNCHEZ-MÁRQUEZ, Juan†๋, FUENTES-RAMÍREZ, Rosalba and GAMIÑO-ARROYO, Zeferino \\ Universidad de Guanajuato, Division of Natural and Exact Sciences, Department of Chemical Engineering, Noria Alta S/N, \\ Noria Alta, 36050, Guanajuato, Guanajuato, Mexico.
}

ID 1" Author: Juan Antonio, Sánchez-Márquez / ORC ID: 0000-0003-0138-642X, CVU CONACYT ID: 267260

ID $1^{\text {st }}$ Co-author: Rosalba, Fuentes-Ramírez / ORC ID: 0000-0003-0520-3387, CVU CONACYT ID: 202669

ID $2^{\text {nd }}$ Co-author: Zeferino, Gamiño-Arroyo / ORC ID: 0000-0002-6228-8586, CVU CONACYT ID: 40579

DOI: $10.35429 /$ JTI.2021.22.8.1.8

Received January 10, 2021; Accepted June 30, 2021

\begin{abstract}
This work focused on the study of the hexavalent chromium removal process from graphene oxide supported on a cross-linked cellulose acetate and polyacrylic acid polymeric membrane. The membranes were synthesized by the phase inversion method and Graphene oxide was added in proportions of $1 \%$ by weight to the polymeric material. Graphene oxide was obtained from crystalline graphite (Electron Microscope Science, No. 70230). The graphite was oxidized using the improved method of Hummers. The characterization of polymer and graphene oxide was made by Raman spectroscopy. The surface charge and point of zero charge of the materials were evaluated using a potentiometric titration method proposed by Loskutov and Kuzin. The removal of $\mathrm{Cr}$ (VI) was studied as a function of contact time and of initial concentration of $\mathrm{Cr}$ (VI). The removal of $\mathrm{Cr}$ (VI) ( $90 \%)$ mainly occurs in a contact time from 32 to $64 \mathrm{~h}$ when the initial concentration of $\mathrm{Cr}(\mathrm{VI})$ is $1 \mathrm{mg} / \mathrm{L}$.
\end{abstract}

Graphene oxide, Removal, Hexavalent chromium

\begin{abstract}
Resumen
Este trabajo se enfocó al estudio del proceso de remoción de cromo hexavalente a partir de óxido de grafeno soportado sobre una membrana polimérica de acetato de celulosa y ácido poliacrílico entrecruzados. Las membranas fueron sintetizadas por el método de inversión de fases y el óxido de grafeno fue agregado en proporciones de $1 \%$ en peso al material polimérico. El óxido de grafeno fue obtenido a partir de grafito cristalino (Electron Microscope Science, No. 70230). El grafito fue oxidado usando el método de Hummers mejorado. La caracterización del polímero y de óxido de grafeno fue hecha a partir de Espectroscopia Raman. La carga Superficial y el punto de carga cero de los materiales fueron evaluados usando un método de titulación potenciométrica propuesto por Loskutov and Kuzin. La remoción de $\mathrm{Cr}$ (VI) fue estudiada como una función del tiempo de contacto y de la concentración inicial de $\mathrm{Cr}$ (VI). La remoción del $\mathrm{Cr}$ (VI) ( 90\%) ocurrió principalmente en un tiempo de contacto de 32 a $64 \mathrm{~h}$ cuando la concentración inicial de $\mathrm{Cr}(\mathrm{VI})$ fue de $1 \mathrm{mg} / \mathrm{L}$.
\end{abstract}

Óxido de Grafeno, Remoción, Cromo hexavalente

Citation: SÁNCHEZ-MÁRQUEZ, Juan, FUENTES-RAMÍREZ, Rosalba and GAMIÑO-ARROYO, Zeferino. Removal of hexavalent chromium from graphene oxide supported on a cellulose acetate and polyacrylic acid membrane. Journal of Technology and Innovation. 2021. 8-22:1-8.

\footnotetext{
* Correspondence of the Author (Email: ja.sanchez@ugto.mx)

$\uparrow$ Researcher contributing as first author.
} 


\section{Introduction}

Many investigations have been focused on the development of new polymeric membranes for different applications (Wang 2004, 355). Nowadays these membranes are used for the recycling of metals, for the removal of toxic products or chemical species, and for obtaining high purity chemicals and clean wastes (Sivakumar 2006, 208). To reach these important applications, a great effort has been placed on the design of new membranes with high selectivity and chemical resistance. Furthermore, it is possible to impose to the membranes an additional requirement related to the possibility to control their selectivity or their properties by changing some external parameters (Rodríguez 2005, 1). The addition of fillers in polymers is an attractive method to obtain materials with novel properties. Nowadays graphene oxide is used as filler to produce new materials. However, when new applications graphene or graphene oxide are proposed, these materials need to be supported on other materials to obtain attractive composite structures with a better performance than the performance showed by pure initial components. The physicochemical characteristics of the membranes obtained from the polymer mixture can be changed if the membrane is prepared using different mixing ratios of the polymers (Sivakumar 1998, 311).

In this work, synthetic polymeric membranes made from polyacrylic acid, cellulose acetate and graphitic materials were prepared and characterized to evaluate their properties, stability, and their possible application in the chromium removal. The use of polymers provides support to graphene oxide and permits its use in continuous processes for the removal of ions. This idea is based on previous studies showing that these materials have great potential in the adsorption of heavy metals (Gadupudi 2007, 224), (Tuzen 2007, 219) and (Hu 2009, 1542).

Chromium is a heavy metal and has been identified as a contaminant of water and soil. Chromium pollution is produced from numerous industrial activities, such as the textile industry, the chemical industry and metallurgy (Kim 2002, 155), (Dönmez 2002, 751) and (Castiblanco 2021, 6).
The $\mathrm{Cr}$ (III) is poorly soluble and stable, is found primarily in food and is essential to maintain normal glucose metabolism in humans. On the other hand, the Cr (VI) is less stable and more soluble and is considered an environmental pollutant, is also toxic and carcinogenic to humans. Hexavalent chromium is harmful to health, relating to certain diseases of the liver, kidney, lungs, and different kinds of cancer (Todorovska 2007, 230).

Composites based on reduced graphene oxide and iron hydroxide have been used for removal of arsenic from aqueous solutions in different studies. Reports show that materials supported on either graphene oxide (GO) or reduced graphene oxide (RGO) have an increased binding capacity compared to free particles (Chandra 2010, 3979), (Hu 2010, 4317), (Ramírez 2021, 22) and (Zhang 2010, 162). Additionally, composites made from reduced graphene oxide and silver oxide have been tested for the removal of $\mathrm{Hg}$ (II) from water. The composites studied showed improvements in the ability of removal of $\mathrm{Hg}$ (II) compared to activated carbon-based materials. Besides, graphene oxide has been used in the detection of different trace metal ions such as $\mathrm{Cu}+2, \mathrm{~Pb}+2$ y $\mathrm{Cd}+2$, showing high sensitivity (Bin 2011, 31). Finally, it is important to point that the performance of nanomaterial in the polymer matrix must be evaluated from the study of conditions such as load, degree of oxidation, polymer features, synthesis conditions and carbon nanomaterial production and precursors. All these features play an important role in the final properties of membranes for chromium removal.

\section{Methodology}

\section{Graphene oxide synthesis (OG)}

The graphite (crystalline graphite of Electron Microscope Science, No. 70230). was oxidized using the improved method of Hummers (Bin 2011, 31). A mixture of graphite, sulfuric acid (Jalmek, purity: 95-98 \%, MW: $98.08 \mathrm{~g} / \mathrm{mol}$ ) and potassium permanganate (JT Baker). The oxidation reaction was conducted at $35{ }^{\circ} \mathrm{C}$, with a range of $+/-3{ }^{\circ} \mathrm{C}$, for $2 \mathrm{~h}$, with a constant medium agitation. Then, the flask was removed from the heat and $92 \mathrm{~mL}$ of distilled water was slowly added to the flask. The solution was kept under magnetic stirring for $15 \mathrm{~min}$.

SÁNCHEZ-MÁRQUEZ, Juan, FUENTES-RAMÍREZ, Rosalba and GAMIÑO-ARROYO, Zeferino. Removal of hexavalent chromium from graphene oxide supported on a cellulose acetate and polyacrylic acid membrane. Journal of Technology and Innovation. 2021 
Next, a mixture of $270 \mathrm{~mL}$ of distilled water and $10 \mathrm{~mL}$ of hydrogen peroxide (J. T Baker, $30 \%$ weight) was added. The final solution was washed with distilled water and the material obtained was dried at $65{ }^{\circ} \mathrm{C}\left(+/-2{ }^{\circ} \mathrm{C}\right)$ for $12 \mathrm{~h}$. Graphene oxide was obtained from a sample of graphite oxide. The sample of graphite oxide was mixed with distilled water. This mixture was placed in an ultrasonic bath (Branson, Model 1510R-MTH) for $3 \mathrm{~h}$ at a frequency of $50-60 \mathrm{~Hz}$. After this time, the solution was filtered and dried for later use.

\section{Synthesis of composite from cellulose acetate and polyacrylic acid}

The composites were synthesized from cellulose acetate (Sigma Aldrich) with a molecular weight of 50,000 by Gel permeation chromatography (GPC) and a degree of acetylation of $39.7 \%$ weight and polyacrylic acid in aqueous solution (Sigma Aldrich) with a molecular weight of $30,000 \mathrm{~g} \mathrm{~mol}^{-1}$ and a percentage of $35 \%$ weight. All commercial reagents were used without any further purification step. Composite was prepared according to a procedure previously reported (Estrada 2010, 3). Initially, a solution was prepared dissolving $8 \mathrm{~g}$ of cellulose acetate in $100 \mathrm{~mL}$ of glacial acetic acid at room temperature. Then, when the cellulose acetate had been completely dissolved, $10 \mathrm{~mL}$ of polyacrylic acid was added slowly with a constant medium agitation; this solution was heated at $60{ }^{\circ} \mathrm{C}$ under agitation for $30 \mathrm{~min}$, allowing the crosslinking reaction between the cellulose acetate and the polyacrylic acid to take place. The final solution was cooled down to room temperature and stored for 3 days before use. To obtain the composites, several samples were poured into flat glad molds of $10 \mathrm{~cm}$ in diameter, leaving the molds with the solution floating on iced water at $4{ }^{\circ} \mathrm{C}$, allowing the solution to reach the same temperature of iced water. Thereafter, the mold with the polymer solution was completely immersed carefully into the cold water until the composites formed and subsequently permitted to rest for $15 \mathrm{~min}$ to allow the solidification of polymer solution. Once the composites were formed, they were withdrawn from the iced water and immediately placed into a bath of hot water at $60{ }^{\circ} \mathrm{C}$. This procedure was applied to composites both with and without graphene oxide using concentrations of $1 \%$ by weight.

\section{Surface characterization}

The characterization of polymer and graphene oxide was made by Raman spectroscopy. The SEM images to the rest of materials were determined with an environmental scanning electron microscope (MEBA, PHILIPS: Model XL30) operated in the high vacuum mode too. The effective surface area and pore size distribution of the graphite materials were determined using N2-BET (ASAP 2010 V5.03).

\section{Results}

\section{Raman spectra (crosslinked polymer)}

The fundamental bands of cellulose acetate have been annotated on the Graphic 1. The characteristic Raman signals for cellulose were present at 2934 and $1121 \mathrm{~cm}^{-1}$, which are attributed to $\mathrm{C}-\mathrm{H}$ stretching and asymmetric stretching vibration of the $\mathrm{C}-\mathrm{O}-\mathrm{C}$ glycosidic linkage, respectively. In addition, we observed the pyranose ring signal at $1081 \mathrm{~cm}^{-1}$ and the band associated with the $\mathrm{C}-\mathrm{OH}$ bonds present in the rings at $1265 \mathrm{~cm}^{-1}$. The characteristic Raman signals for the acetyl group can be observed in 1736, 1435 and $1382 \mathrm{~cm}^{-1}$ corresponding to vibration of the carbonyl group $(\mathrm{C}=\mathrm{O})$ and asymmetric and symmetric vibrations of the $\mathrm{C}$ $\mathrm{H}$ bond present in the acetyl groups. The signals observed at 978, 906,834 and 659 can be associated with $\mathrm{C}-\mathrm{O}, \mathrm{C}-\mathrm{H}$, and $\mathrm{O}-\mathrm{H}$ and $\mathrm{C}-\mathrm{OH}$ bonds, respectively.

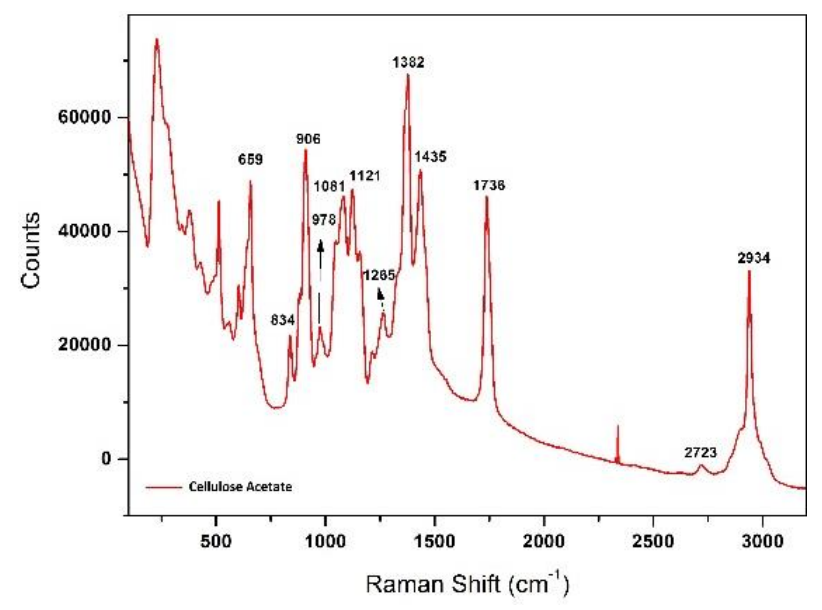

Graphic 1 Raman spectra of cellulose Acetate

The spectrum for the polyacrylic acid is shown in graphic 2. The characteristic Raman signals can be observed at 3444 and $1678 \mathrm{~cm}^{-1}$ corresponding with the oxygen-hydrogen bond vibration and carbonyl group $(\mathrm{C}=\mathrm{O})$ vibration present in the carboxylic groups.

SÁNCHEZ-MÁRQUEZ, Juan, FUENTES-RAMÍREZ, Rosalba and GAMIÑO-ARROYO, Zeferino. Removal of hexavalent chromium from graphene oxide supported on a cellulose acetate and polyacrylic acid membrane. Journal of Technology and Innovation. 2021 
The stretching vibrations of the carboncarbon double bond $(\mathrm{C}=\mathrm{C})$ appear at $1654 \mathrm{~cm}^{-1}$ while in-plane bending of the $\mathrm{O}-\mathrm{H}$ bond can be placed at $1496 \mathrm{~cm}^{-1}$. Finally, the bands at 1306 , 1224 and 905 corresponding to $\mathrm{C}-\mathrm{O}$ bond vibrations.

The peak at $1224 \mathrm{~cm}^{-1}$ had a contribution from C-C bonds presents.

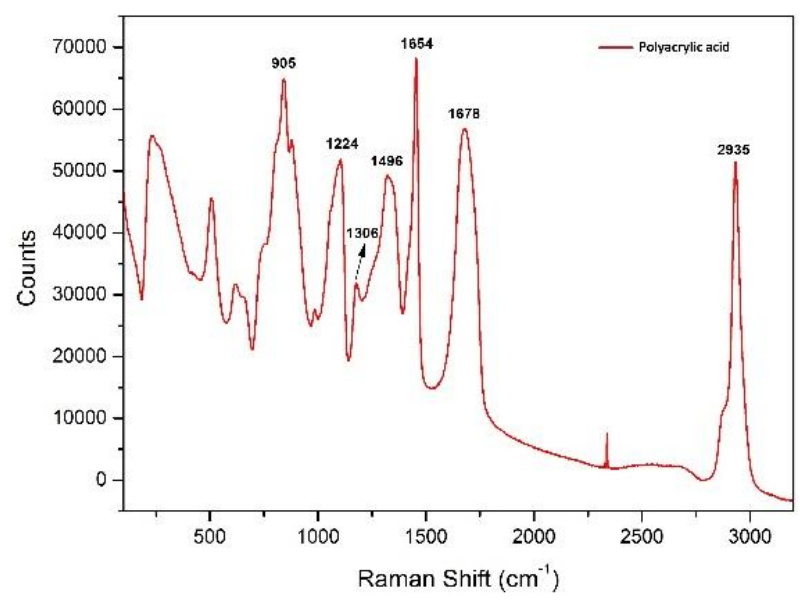

Graphic 2 Raman spectra of polyacrylic acid

When the crosslinking reaction takes place, the spectrum obtained shows primarily the characteristic Raman signals for the cellulose acetate while polyacrylic acid has remained undetected because their bands partially overlapped those of cellulose acetate, as shown in Graphic 3. The characteristic Raman signals for crosslinked polymer were present at 2939 and $1121 \mathrm{~cm}^{-1}$, which are attributed to $\mathrm{C}-\mathrm{H}$ stretching and asymmetric stretching vibration of the C-O$\mathrm{C}$ glycosidic linkage, respectively. In addition, we observed the pyranose ring signal at $1081 \mathrm{~cm}^{-}$ ${ }^{1}$ and the characteristic Raman signals for the acetyl group in 1731,1431 and $1368 \mathrm{~cm}^{-1}$ corresponding to vibration of the carbonyl group $(\mathrm{C}=\mathrm{O})$ and asymmetric and symmetric vibrations of the $\mathrm{C}-\mathrm{H}$ bond present in the acetyl groups, respectively. Finally, the signals observed at 978, 906, 834 and 659 can be associated with $\mathrm{C}-\mathrm{O}, \mathrm{C}-\mathrm{H}$, and $\mathrm{O}-\mathrm{H}$ and $\mathrm{C}-\mathrm{OH}$ bonds, respectively. For crosslinked polymer we cannot observed the band associated with the C$\mathrm{OH}$ bonds present in the glycosidic rings at 1265 $\mathrm{cm}^{-1}$ and we cannot see the characteristic Raman signals at 3444 and $1678 \mathrm{~cm}^{-1}$ corresponding with the oxygen-hydrogen bond vibration and carbonyl group $(\mathrm{C}=\mathrm{O})$ vibration present in the polyacrylic acid neither.

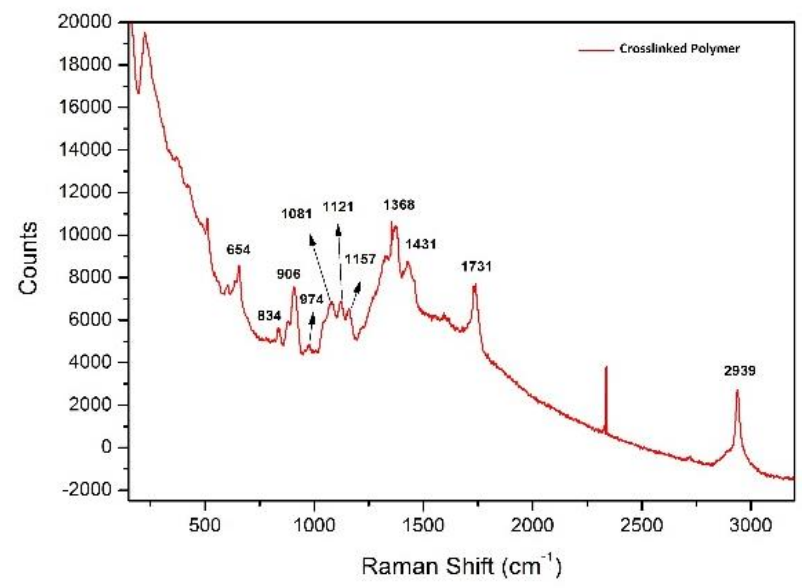

Graphic 3 Raman spectra of crosslinked polymer

The IR spectra of polymer with materials made from graphite are shown in Graphic 4. These spectra show the characteristic peaks of the polymer crosslinked. In addition, it is not possible to observe interactions between the polymer and graphite materials from IR spectra.

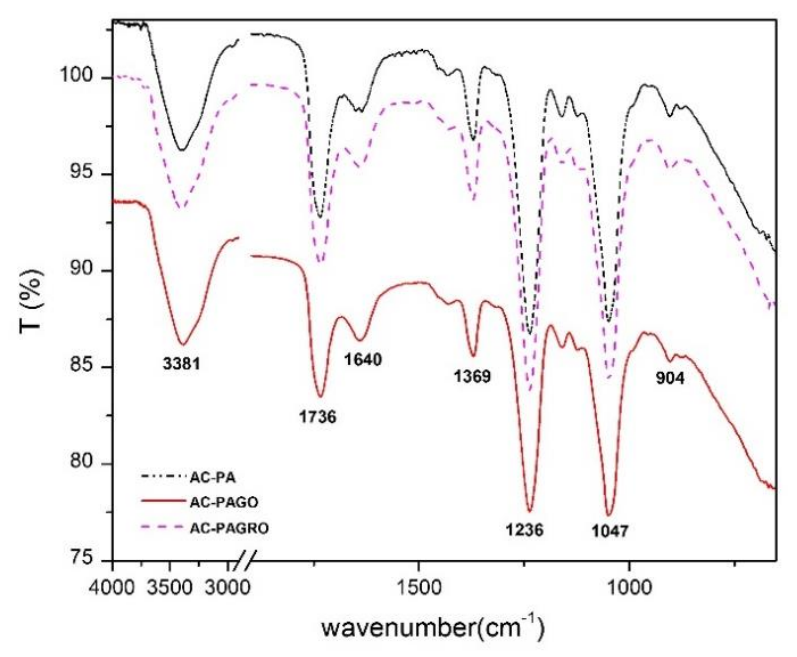

Graphic 4 Infrared spectra of the crosslinked polymer (AC-PA) and the crosslinked polymer with graphite oxide (AC-PAGO) and graphene oxide (AC-PAGRO)

\section{Scanning electron microscopy}

The images obtained from electron microscopy are shown in Graphic 5. 


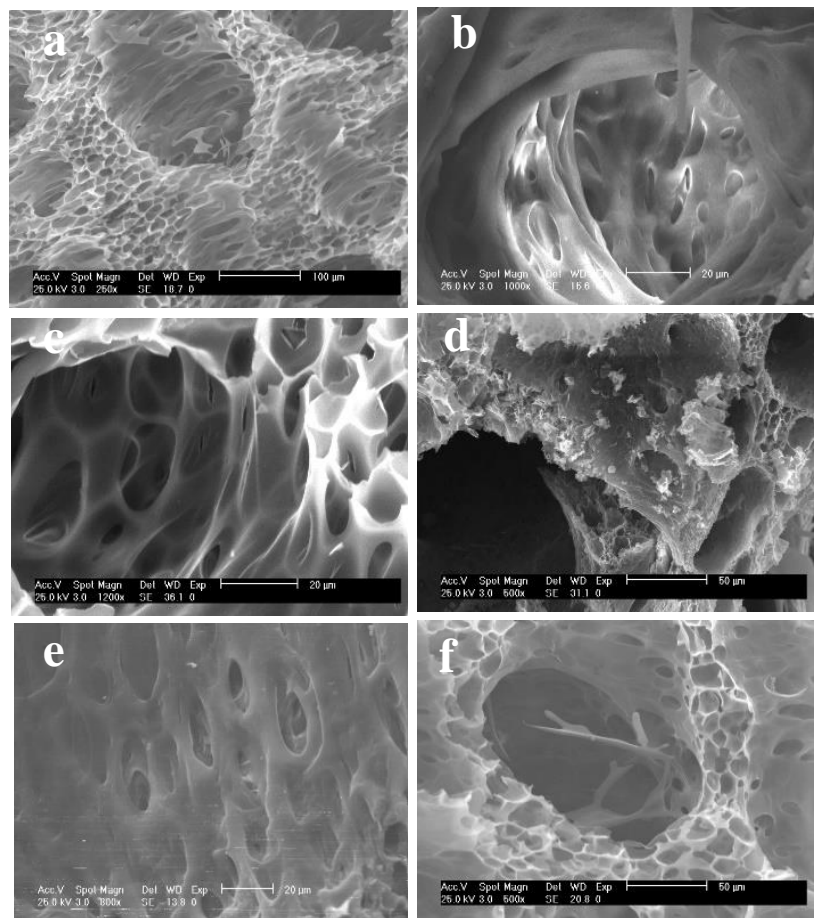

Graphic 5 Sequence of scanning electron microscope images for different polymeric materials. (a), (b) and (d) Graphite oxide, (c), (e) and (f) Graphene oxide.

The figures correspond to the different kind of membranes synthetized. In accordance with the results obtained from the microscopic characterization, we can say that the polymeric membranes have pores of variable size. In some membranes, the pores are formed in layers, giving the effect of forming a deep network, Graphic 5a, 5c and 5e. For the materials obtained from graphite we can observed that the graphitic material is deposited on the walls of the pores within the polymer structure, Graphic 5d and 5f, respectively. Both graphite oxide as graphene oxide cover the walls of the material and they improve the structure polymer.

\section{Determination of the surface area and pore size distribution in the graphene oxide}

The BET analysis was applied to graphene oxide to determine the effective surface area and the pore size distribution of the material. The effective surface area of graphite $\left(7.73 \mathrm{~m}^{2} / \mathrm{g}\right)$, graphite oxide $\left(2.85 \mathrm{~m}^{2} / \mathrm{g}\right)$ and graphene oxide $\left(20.86 \mathrm{~m}^{2} / \mathrm{g}\right)$ were calculated with the same method. The average pore size for samples of graphite $(9.4 \mathrm{~nm})$, graphite oxide $(8.9 \mathrm{~nm})$ and graphene oxide $(10 \mathrm{~nm})$ showed small variations.
In the case of graphene oxide, the adsorption-desorption isotherms obtained by BET analysis, Graphic 6, showed a characteristic behaviour of the isotherm of type 3 proposed by Brunauer, which shows that the adsorption occurs by a physical mechanism. From adsorption-desorption isotherms obtained we can see that the analysed samples have a hexagonal tubular capillary.

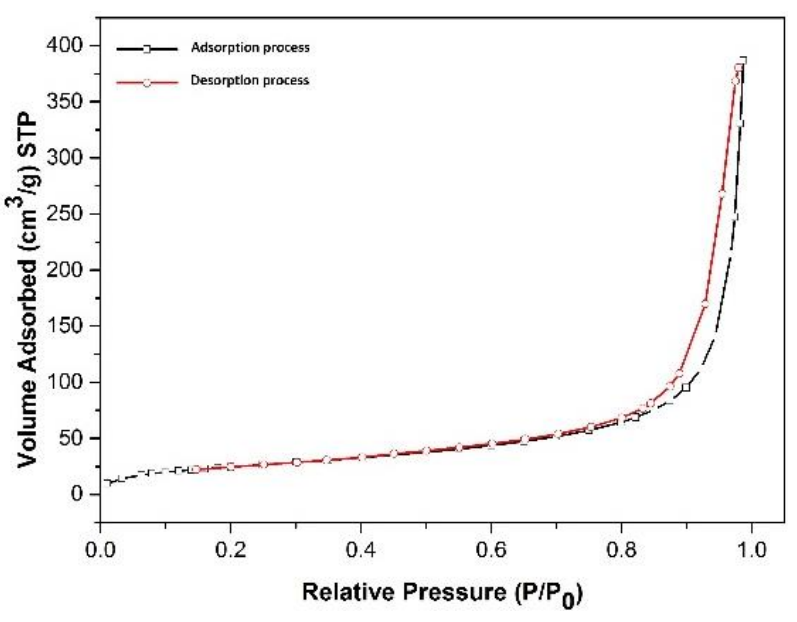

Graphic 6 Adsorption-desorption isotherm of graphene oxide

\section{Concentration of acidic sites and basic sites}

Both, acidic and basic sites were calculated in graphene oxide and polymeric materials using a method proposed by Böehm based in an acidbase titration. For the graphite oxide and graphene oxide, concentration values for only the acid sites were obtained. The graphene oxide $(2.28 \mathrm{meq} / \mathrm{g})$ showed a higher concentration of acid sites than graphite oxide (1.45 meq/g). Both, acidic and basic sites on the membranes without graphitic material were calculated using the method proposed by Böehm. The concentration of acidic sites in the polymeric material ( $4.9 \mathrm{meq} / \mathrm{g}$ ) is 1.25 times higher than the concentration of base sites $(3.9 \mathrm{meq} / \mathrm{g})$. The basic sites in the polymeric material may be associated with unreacted sites on the cellulose; while the acid sites can be ascribed to sites vacated in the polyacrylic acid during the synthesis process of the copolymer. For the membranes with graphitic materials, significant changes in the concentration values of the sites were not observed. 


\section{Surface charge and zero-point load}

The surface charge of the graphene oxide and reinforced membranes was placed using a method proposed by Loskutov Kuzin based in a potentiometric titration. The zero-point load for the graphite oxide and graphene oxide was determined in a $\mathrm{pH}$ value of 2.8 and 2.7, respectively. Thus, the materials are positively charged at $\mathrm{pH}$ values lower than load point zero and negatively at $\mathrm{pH}$ values higher than load point zero, Graphic 7a-7b. For the polymeric membranes, the zero-point load was placed in a $\mathrm{pH}$ value of 2.2, Graphic 7c. The surface of polymeric membranes is positively charged at $\mathrm{pH}$ values higher than the zero-point load and negatively charged at $\mathrm{pH}$ values lower than the zero-point load. The behaviour of the surface charge of the membranes is opposite to the behaviour shown by graphite materials. The membranes with graphitic material showed a zero-point load placed at $\mathrm{pH}$ values higher than those shown for the membranes without graphitic material, Graphic 7d-7e. The surface of polymeric membranes with graphitic material is positively charged at $\mathrm{pH}$ values higher than the zero-point load and negatively charged at $\mathrm{pH}$ values lower than the zero-point load.
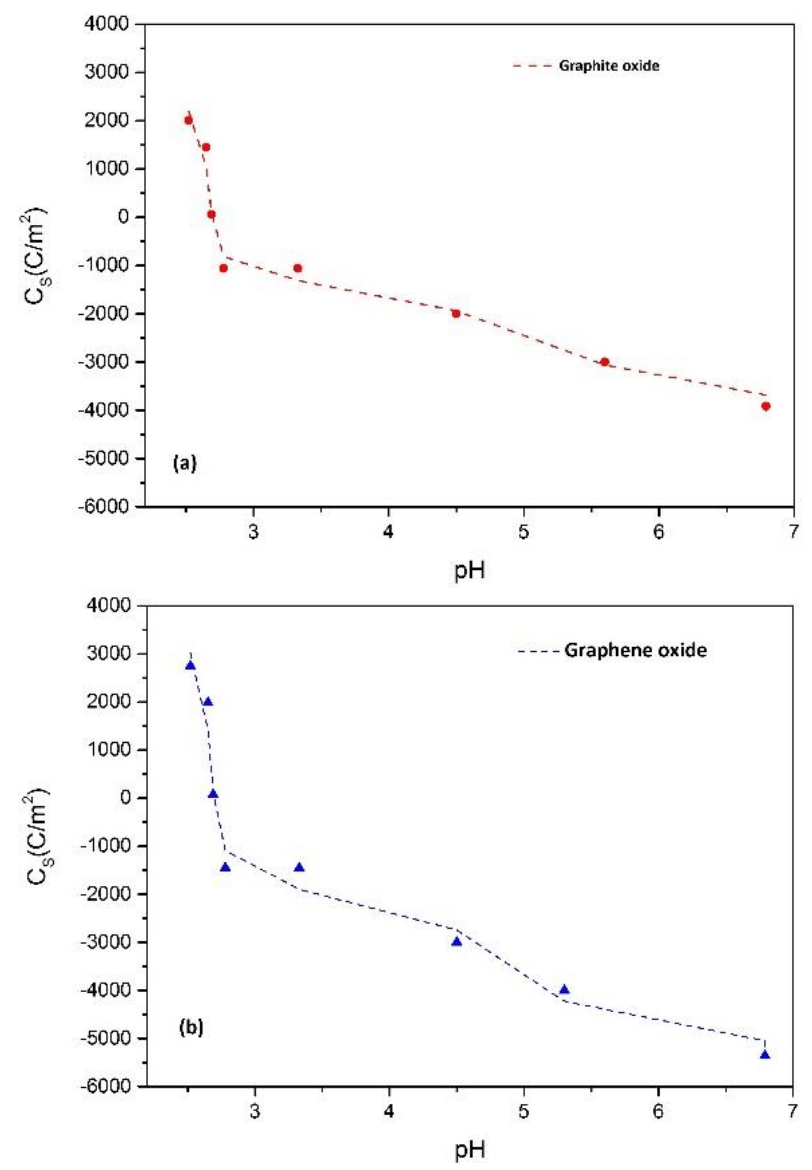
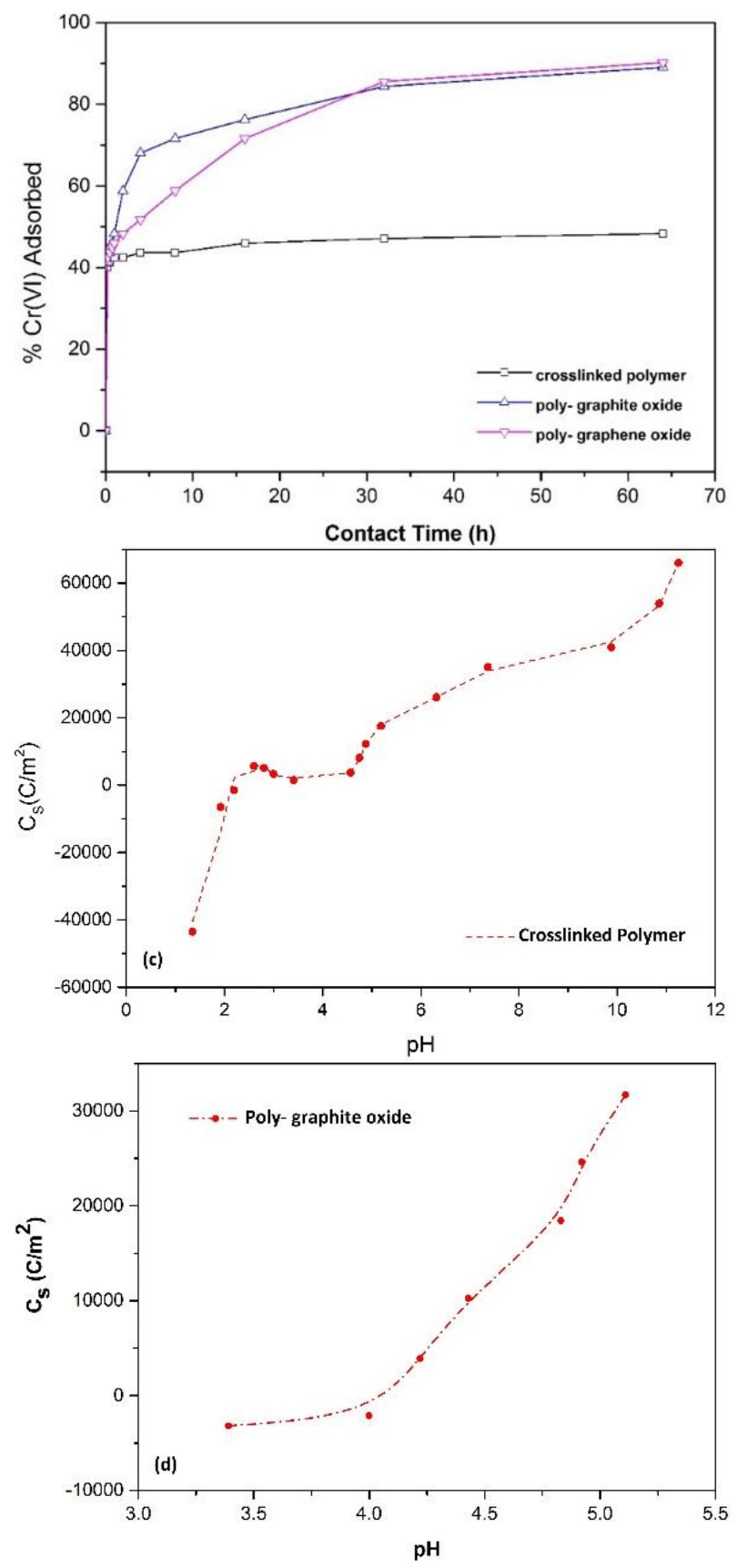

Graphic 7 Distribution of the surface charge in the different materials: a-b) Graphite and graphene oxide, c) Crosslinked polymer and d-e) Crosslinked polymer with graphite and graphene oxide

\section{Effect of contact time}

The removal of $\mathrm{Cr}(\mathrm{VI})$ from aqueous solutions using polymeric materials made from cellulose acetate and polyacrylic acid with graphite materials was studied as a function of contact time at a $\mathrm{pH}$ value of 2.2. From the adsorption kinetics obtained the removal of $\mathrm{C} r(\mathrm{VI})$ increases when the contact time increases, Graphic 8. The removal of $\mathrm{Cr}$ (VI) mainly occurs in a contact time from 32 to $64 \mathrm{~h}$ when the initial concentration of $\mathrm{Cr}$ (VI) is $1 \mathrm{mg} / \mathrm{L}$ and the charge of graphitic material in the membranes is $1 \%$ by weight, Graphic 9 .

SÁNCHEZ-MÁRQUEZ, Juan, FUENTES-RAMÍREZ, Rosalba and GAMIÑO-ARROYO, Zeferino. Removal of hexavalent chromium from graphene oxide supported on a cellulose acetate and polyacrylic acid membrane. Journal of Technology and Innovation. 2021 


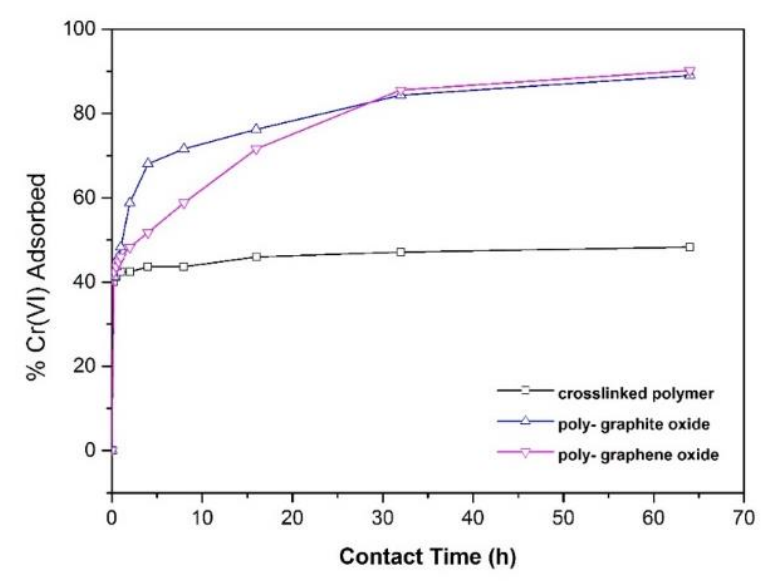

Graphic 8 Chromium adsorption kinetics for polymeric membranes with graphite and graphene oxide ( $\mathrm{pH} 2.2)$

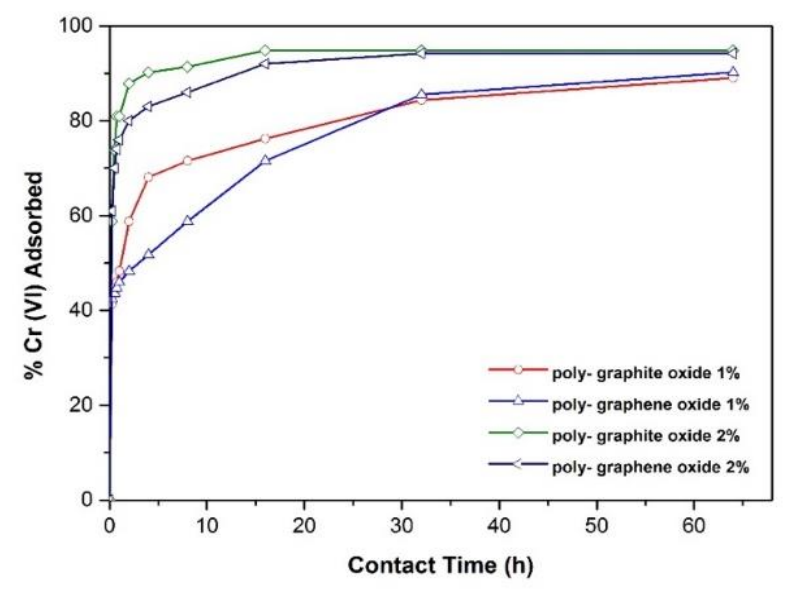

Graphic 9 Chromium adsorption kinetics for polymeric membranes with graphite

\section{Effect of initial concentration of $\mathrm{Cr}(\mathrm{VI})$}

The effect of initial concentration of $\mathrm{Cr}(\mathrm{VI})$ on removal of metal was studied using polymeric materials with graphitic materials. The data were obtained at a pH value of 2.2 and different temperatures. For the materials studied, the removal percentage of $\mathrm{Cr}(\mathrm{VI})$ decreases with the increase of the initial concentration of chromium. When the dose of the graphitic material is constant, the availability of surface adsorption sites also remains fixed; in this way, the removal percentage decrease is due to electrostatic repulsion between ions. When the concentration increases, the competition between ions also increases, thus increasing the electrostatic repulsion. The data of the amount of $\mathrm{Cr}$ (VI) adsorbed on the polymer graphitic materials (q, $\mathrm{mg} / \mathrm{g}$ ) and the concentration of $\mathrm{Cr}$ (VI) remaining in solution $(\mathrm{Ce}, \mathrm{mg} / \mathrm{L})$ are described in a better way by the model Langmuir for the temperatures studied, Table 1.

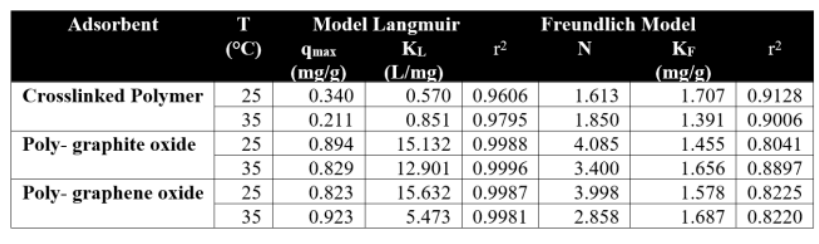

Table 1 Parameters langmuir model and freundlich model

\section{Conclusions}

The results obtained show that it is possible to design polymers with graphitic materials whose pores are formed in layers, giving the effect of depth forming a network. The graphitic material is deposited on the outside of the polymeric material. The adsorption-desorption isotherms obtained by BET analysis showed that the adsorption occurs by a physical mechanism and that the analysed samples have a hexagonal tubular capillary. Besides, the isotherms of adsorption / desorption obtained for graphite, graphite oxide and graphene oxide showed characteristics like the carbon nanotubes. For the graphite, graphite oxide and graphene oxide, concentration values for only the acid sites were obtained. These acid sites can be associated with the presence of carboxylic groups inserted during oxidation of the graphitic materials. The basic sites in the polymeric material may be associated with unreacted sites on the cellulose; while the acid sites can be ascribed to sites vacated in the polyacrylic acid during the synthesis process of the copolymer. For the membranes with graphitic materials, no significant changes were observed in the concentration values of the sites.

The graphitic materials are positively charged at $\mathrm{pH}$ values lower than load point zero and negatively at $\mathrm{pH}$ values higher than load point zero. While the surface of polymeric membranes is positively charged at $\mathrm{pH}$ values higher than the zero-point load and negatively charged at $\mathrm{pH}$ values lower than the zero-point load. Thus, the behaviour of the surface charge of the membranes is opposite to the behaviour shown by graphite materials. From these studies of removal of $\mathrm{Cr}(\mathrm{VI})$ on the membranes we can establish the following conclusions:

- $\quad$ The removal of Cr (VI) using polymeric membranes with and without graphite and graphene oxide is strongly dependent of the $\mathrm{pH}$ values. Besides, the adsorption of $\mathrm{Cr}$ (VI) decreases with the increase of $\mathrm{pH}$ value.

SÁNCHEZ-MÁRQUEZ, Juan, FUENTES-RAMÍREZ, Rosalba and GAMIÑO-ARROYO, Zeferino. Removal of hexavalent chromium from graphene oxide supported on a cellulose acetate and polyacrylic acid membrane. Journal of Technology and Innovation. 2021 
- $\quad$ The adsorption of Cr (VI) using polymeric membranes with and without graphite and graphene oxide is fast in the beginning of the process and then becomes slow with increased contact time.

The removal of $\mathrm{Cr}$ (VI) takes a considerable time when using polymeric membranes with and without graphite and graphene oxide as adsorbents.

The kinetics of absorption of $\mathrm{Cr}$ (VI) can be represented by models of pseudo second order and pseudo first order.

\section{Acknowledgement}

This work was supported by the Universidad de Guanajuato and PRODEP Program. We thank M.T. Carrillo for her help in revising the manuscript.

\section{References}

Bin W., Yan-Hong C., Lin-jie Z. (2011), High yield production of graphene and its improved property in detecting heavy metal ions, University of Science and Technology of Beijing, China, New Carbon Materials, 26(1), 31-35

Castiblanco R., D. A. (2021). Aproximación a la remediación de efluentes industriales provenientes de sector curtiembres en Bogotá a través de una solución nanotecnológica, Universidad Antonio Nariño

Chandra V., Park J., Chun Y., Lee J.W., Hwang I.-C., Kim K.S. (2010), Water-dispersible magnetite-reduced graphene oxide composites for arsenic removal, ACS Nano 4, 3979-3986.

Dönmez G., Aksu Z. (2002), Removal of chromium (VI) from saline wastewaters by Dunaliella species, Proc. Biochem. 38, 751-762.

Estrada R., Rubio E., Rodríguez V. (2010), Nonlinear changes in pore size induced by temperature in the design of Smart membranes, Polymer Journal, 1-5.

Gadupudi R., Chungsying L., Fengsheng S. (2007), Sorption of divalent metal ions from aqueous solution by carbon nanotubes: A review, Application of Nanotechnologies in Separation and Purification, 58, 224-231.
Hu W., Peng C., Luo W., Lv M., Li X., Li D., Huang Q., Fan C. (2010), Graphene-based antibacterial paper, ACS Nano 4, 4317-4323.

Kim S.D., Park K.S., Gu M.B. (2002), Toxicity of hexavalent chromium to Daphnia magna: influence of reduction reaction by ferrous iron, J. Hazard. Mater. A93, 155-164.

Ramírez Panti, R. I. (2021). Preparación de composito basado en oxido de grafeno y zeolita aplicado como material adsorbente en colorantes textiles, Universidad Nacional José Faustino Sánchez Carrión.

Rodríguez, R. \& Castaño, V. M. (2005), Smart membranes: a physical model for a circadian behavior. Appl. Phys. Lett. 87, 1-3

Sivakumar M., Mohan D., Rangarajan R. (1998), Preparation and performance of cellulose acetate-polyurethane blend membranes and their applications. Part 1, Polym. Int. 47, 311316.

Sivakumar M., Mohan D.R., Rangarajan R. (2006), Studies on cellulose acetatepolysulfone ultrafiltration membranes. II. Effect of additive concentration, J. Membr. Sci. 268, 208-219.

Todorovska N., Karadjova I., Arpadjan S., Stafilov T. (2007), On chromium direct ETAAS determination in serum and urine, Central European Journal of Chemistry, 5, 1, 230-238

Tuzen M., Soylak M. (2007), Multiwalled carbon nanotubes for speciation of chromium in environmental samples, Journal of Hazardous Materials 147, 219-225

Wang Z.F., Wang B., Ding X.M., Zhang M., Liu L.M., Qi N., Hu J.L. (2004), Effect of temperature and structure on the free volume and water vapor permeability in hydrophilic polyurethanes, J. Membr. Sci. 24, 355-361.

Zhang K., Dwivedi V., Chi C., Wu J. (2010), Graphene oxide/ferric hydroxide composites for efficient arsenate removal from drinking water, J. Hazard. Mater. 182, 162-168

SÁNCHEZ-MÁRQUEZ, Juan, FUENTES-RAMÍREZ, Rosalba and GAMIÑO-ARROYO, Zeferino. Removal of hexavalent chromium from graphene oxide supported on a cellulose acetate and polyacrylic acid membrane. Journal of Technology and Innovation. 2021 